\title{
Prospects for the Development of Sustainable Tourism in the Okinsky District of the Republic of Buryatia
}

\author{
Maria Kuklina ${ }^{1, *(D)}$, Andrey Trufanov ${ }^{2} \mathbb{D}$, Natalia Krasnoshtanova ${ }^{3}$, Nina Urazova ${ }^{2}$, Dmitrii Kobylkin ${ }^{3}$ and \\ Marina Bogatyreva 4 \\ 1 Institute of High Technology, Irkutsk National Research Technical University, 83, Lermontova st., \\ 664074 Irkutsk, Russia \\ 2 Institute of Information Technology and Data Science, Irkutsk National Research Technical University, \\ 83, Lermontova st., 664074 Irkutsk, Russia; troufan@gmail.com (A.T.); urazova_nina@mail.ru (N.U.) \\ 3 V B Sochava Institute of Geography SB RAS, 1, Ulan-Batorskaya st., 664033 Irkutsk, Russia; \\ knesun@mail.ru (N.K.); agrembrandt@inbox.ru (D.K.) \\ 4 Institute of Economics, Management and Law, Irkutsk National Research Technical University, \\ 83, Lermontova st., 664074 Irkutsk, Russia; bmv2005@listl.ru \\ * Correspondence: kuklina-kmv@yandex.ru; Tel.: +7-9246246249
}

Citation: Kuklina, M.; Trufanov, A.; Krasnoshtanova, N.; Urazova, N.;

Kobylkin, D.; Bogatyreva, M.

Prospects for the Development of Sustainable Tourism in the Okinsky District of the Republic of Buryatia. Sustainability 2021, 13, 8042. https:// doi.org/10.3390/su13148042

Academic Editor: Jonathon Day

Received: 31 May 2021

Accepted: 12 July 2021

Published: 19 July 2021

Publisher's Note: MDPI stays neutral with regard to jurisdictional claims in published maps and institutional affiliations.

\begin{abstract}
This article discusses the prospects for the development of sustainable tourism as an element of the network system in Okinsky District, Republic of Buryatia, RF. Before COVID-19related restrictions, the number of tourists in this area increased annually, which was associated with the attractiveness of this terrain for visitors. The potential of the tourism sector of Okinsky District comes from the combination of a large number of natural resources. The area has rich water resources, including rivers, lakes, waterfalls, and mineral springs, with well-preserved mountainous landscapes accompanied by a centuries-old cultural and ethnic heritage. Due to Okinsky District's specific border location and remoteness, the area has a very large number of places for recreation. The objective of our work is to clarify key factors hindering the development of tourism in the district. The study is aimed at examining the state of natural objects and determining their importance for locals, vacationers, and the district as a whole. In this regard, a problem integrity scope and a networked approach to the accompanying analysis reveal the mechanisms that contribute to the conservation of biological diversity of natural objects and their rational, scientifically grounded use in the tourism industry in accordance with the principles of sustainable development. The set of problems that impede the active promotion of tourism were identified. However, these problems are typical not only for the studied district but also many other remote areas of the Russian Federation.
\end{abstract}

Keywords: sustainable tourism; Okinsky District; Republic of Buryatia; map of attractions; holism; network platform; sustainable development

\section{Introduction}

Problems relating to the stability of processes are especially acute when it becomes necessary to choose the best strategies for economic development. As noted in [1], this is important while elaborating long-term and short-term plans and assessing environmental impacts of pertinent decisions. The territories of Eastern Siberia bordering Mongolia are sensitive to such strategic choices. As such, even in the Soviet period, the construction of a hydroelectric power station on the Egiin-Gol River was controversial-it is the most full-flowing of the rivers of Mongolia rising from Lake Khövsgöl, and is distinguished by a constant hydrological regime [2].

The key trend in the development of the modern world economy is a significant increase in the share of services within the structure of the world gross domestic product (GDP). In recent years, the total volume of trade in services has grown fivefold [3]. The rate of development of the tertiary sector of the economy is already outstripping the production 
of material goods, and employment is continuing to grow in the service sector. Pertinent investment activity is noticeable; according to the World Bank [4], in the last decade of the 20 th century, the contribution of the service sector was about $70 \%$ of the world economy in developed countries. In parallel with this, in the 1980s, a new paradigm of social development was formed-the concept of sustainable development, aimed at meeting the needs of modern society in such a way as not to jeopardize those of subsequent generations, but rather to search for a concomitant intergenerational balance.

Modern socio-humanitarian national and international studies by scientists from environmental disciplines do not find specific contradictions in different approaches to or interpretations of the concept of sustainable development; however, different areas of research focus on its various aspects [5-9].

A generally recognized and widely known formulation of sustainable development was produced by the Brundtland Commission (referencing the name of its chairman, Gro Harlem Brundtland), officially the World Commission on Environment and Development (WCED), convened by the United Nations in 1983. This formulation reflects the idea of longterm progress of mankind accompanied by improvement in economic and environmental components of human life. In this interpretation, sustainable development is understood as "development that meets the needs of the present without compromising the ability of future generations to meet their own needs" [10]. This definition does not contradict national Russian legislation, in particular [11], which was created based on sustainability achievements in the world community.

Tourism is one of the most promising sectors of the economy in Baikal region. Rich recreational [12] and ethno-recreational [13] resources can contribute to its development. It has been noted that limited transport accessibility, seasonality, and the lack of qualified personnel and quantity of hotels are the main factors hindering the development of tourism [14]. However, the experience of other countries located in similar geographic zones shows that such regions can nonetheless develop increased tourism (e.g., northern Finland, Yukon Territory in Canada, Alaska in the USA). Infrastructure provision has become integral in such regions [15]. Therefore, it is of great importance to determine the institutional and socio-cultural characteristics of tourism and its prospects within the framework of the sustainable development of a territory.

Development of remote regions of Siberia and the Far East seems promising. This study focuses on Okinsky District in the Republic of Buryatia, which has long attracted many tourists with various interests. Climbers, mountaineers, and lovers of landscape tourism can spend a great deal of time here. The area is also known for its useful mineral springs, Shumak, Zhoigan, and Khoytogol (Figure 1).

1. Alpine and subalpine regions-mountaineering, hiking, horseback-riding routes;

2. Ernikovaya (Betula rotundifolia) mountain tundra and woodlands-hiking, hunting;

3. Dark coniferous taiga valley-hunting, rafting on large rivers, fishing;

4. Light coniferous (larch) taiga with expositional steppe-hiking, hunting;

5. Steppe and forest-steppe valley-hiking and horse trails, fishing, stationary and rural tourism;

6. Most visited landscapes and places of interest (1-Topografov Peak, 2-Valley of Volcanoes, 3-Zhomboloksky lava flow, 4-Saylak waterfall, 5-Orkho-Bom gorge, 6-Aliber graphite mine, 7-Shumak river valley; 8-a group of caves in the Zabit river valley);

7. Mineral springs (1-Shumak, 2-Zhoigan, located in the Republic of Tuva, 3-KhoytoGol, 4-Shutkhulai, 5-Halun-Ugan, 6-Tissinsky, 7-Aynyk);

8. Promising areas for the development of speleotourism;

9. Floatable rivers (actively used and promising);

10. Hiking and horse trails (actively used and promising). 


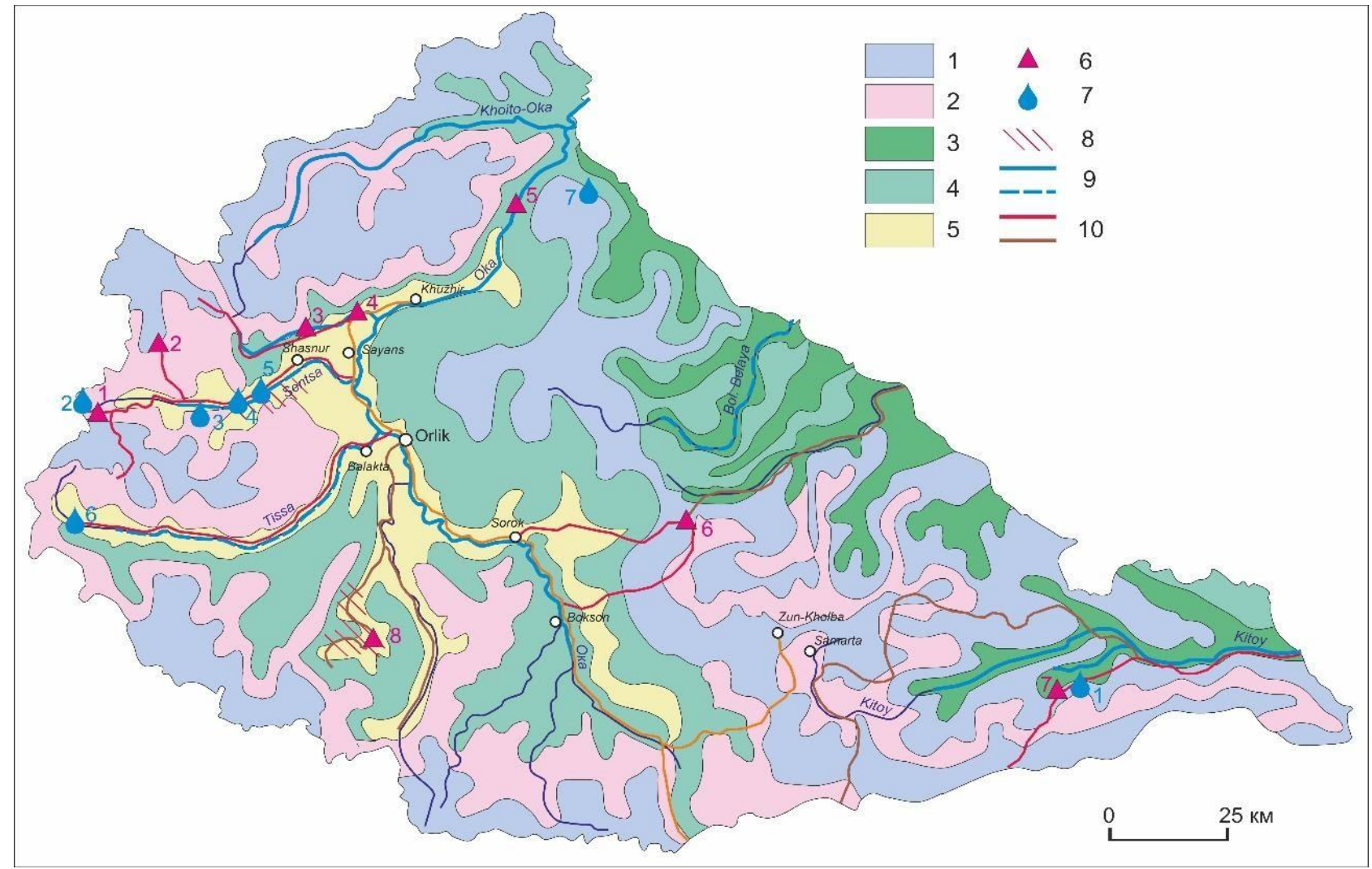

Figure 1. Tourist map of the Okinsky region (our original work of authorship). Landscape belts for tourism development.

Traditionally, the area is visited by water tourists, whose routes pass along the rivers starting in the Okinsky region and flowing into the Angara River. Recently, winter tourism fans have begun to show interest in the natural attractions of the area. Thus, there is an opportunity for formation of tourist infrastructure that will function not in fragments, but continuously throughout the year.

Development of the tourism industry can stimulate an increase in entrepreneurial and investment activity, expansion of international relations, and the solution of socioeconomic problems. Along with those, it is of value to promote and maintain sustainable tourism, preserving the pristine and unspoiled beauty of this terrain, which is so attractive to tourists.

\section{Literature Review}

In some works by Russian authors [16,17], a certain contradictory interpretation of the term "sustainable development" is noted, since the concept of "sustainability" per se implies the equilibrium state of a system, and the concept of "development" predetermines the exit of the system from this state; however, despite such an illogicality, sustainable development can still be seen as rational growth that meets future needs.

A notable contribution to the study issue was made by [18], who modeled interconnections between infrastructure, sustainable tourism development, and respective quality of life as perceived by local people.

Another study [19] examined to what extent the tourism sector was damaged because of COVID-19 and offered ways to get it back to its regular state.

At the same time, the logic of sustainable development has three key indicatorseconomic, social, environmental-and in this, we note, it is consonant with the theory of the noosphere, put forward by V.I. Vernadsky in the middle of the 20th century [20]. Therefore, the concept under study can be viewed from different angles. From the point of view of natural and social sciences, "sustainable development is understood as the development 
of the environment and society, in which the satisfaction of the vital needs of living people is achieved and such an opportunity remains for future generations" [21]. From the standpoint of studying society, "sustainable development is a concept of human development, the principle of which is to meet the needs of the present without creating a threat to meet the needs of future generations" [22]. Economic development is manifested through constant improvement of the quality of life of people. By definition [23], "sustainable development is a program that must change the process of economic development in such a way that it guarantees a basic level of quality of life for all people."

The interdependence of these processes is not unexpected: The rapid growth of industrial production in the second half of the 20th century led humankind to the need for a conscious attitude to problems of limited resources, environmental pollution, and employment for a rapidly growing population.

Among the sectors of the service sphere, tourism occupies a special place. Its share in the world economy exceeds $10 \%$, and in the world export of services it is approximately $30 \%$ [24]. It is supported by high standards of living for people in industrialized countries, which stimulates steady effective demand for tourist services based on an increase in vacation time and high levels of pension provision.

In connection with the above, it should be noted that the concept of sustainable tourism can also be interpreted in different ways. In general, according to the definition of the World Tourism Organization (WTO), the objective of sustainable tourism is to retain the economic and social advantages of tourism development while reducing or mitigating any undesirable impacts on the natural, historical, cultural, or social environment. This is achieved by balancing the needs of tourists with those of the destination [25]. As can be seen from the definition, it reflects principal aspects of the basic concept (societyeconomy-ecology).

Among Russian studies devoted to the impact of tourism on the world economy, a significant one is the work [26], in which a deep analysis of approaches to the definition of the concept of sustainable tourism was performed. It considered the point of view of total relations and phenomena occurring as a result of travel, also reflecting interests of citizens who temporarily stay with a variety of purposes, from medical to recreational and from recreational to religious, and, especially important for this study, took into account the socio-cultural, economic, and geographical features of the host country.

The concept was also examined in [23], based on ensuring optimal use of environmental resources and supporting socio-cultural characteristics of host communities. This approach is consonant with studies [27] in which sustainable tourism was understood as a similar development of long-term tourism, in which a balance is achieved in the implementation of economic, environmental, social, and cultural development goals, and the interests of all stakeholders (tourists, tourism organizations and operators, and local populations), based on the rational use of tourism resources and supported by comprehensive partnership. Considering all these aspects, sustainable tourism is a direction in tourism that meets the needs of society, preserves what has been achieved, and increases the opportunities for the future.

Local populations also put influence on the tourism industry and its development. Links between the religious life of residents and the socio-cultural impact of sustainable tourism were explored in [28].

Tourism is one of few sectors of the economy that, despite the economic and political crises, has achieved steady growth in key indicators-up to four percent per year, which amounted to seven percent of global trade [29,30]. Despite constantly changing preferences of tourists and demands of traveling people, this growth remained stable before the pandemic initiated by SARS CoV-2. This stability was due to development of information and communication technologies, which launched changes in the working technologies of tourist firms and hotels, and organizational processes within companies' activities. 
For almost three decades, the scientific community has been actively performing research on the place and role of tourism in achieving sustainable development goals: from understanding the global nature of the phenomenon [31], to analyzing indicators of sustainable tourism in relation to sustainable development goals [32,33], to balancing the requirements of tourism development with environmental protection. Recent research in this area concerns the need for a radical rethinking of public consciousness-mentalities of tourists and attitudes of creators of tourism products - and concerns assessing the impact of tourism on the environment

The remarkable work [34] apposed the problem of interdependency between lowcarbon-based policy and the tourism industry. It is of significance that the authors proposed an evaluation model that extracts quantitative data from subjective qualitative information of low-carbon tourism, taking into account interconnection covering economic, environmental, and social subsystems. To collect evaluation indicators, they used diverse sources, including expert interviews. Principally, such a model could be applicable for counteracting climate change, as well as in response to other threats while realizing tourism activity.

The concept of sustainable tourism is an alternative to mass tourism [35], which entails a significant recreational burden. Its uncontrolled development causes destruction of unique natural objects, a decrease in biodiversity, the degradation of cultural landscapes, decreased attractiveness of the destination, etc. The very notion of sustainable tourism uncovers the fact that it must meet the needs of modern tourists and local populations while preserving and increasing opportunities for the future [36,37].

On the other hand, one should remember that tourism is characterized as a sphere of the economy that creates a large number of jobs. Thus, the development of tourism is aimed at the implementation of important social functions: the creation of jobs for such categories of the population as youth, women, and rural residents (especially concerning the development of ecological and ethnic tourism). At the same time, one notes that the sphere does not require high qualifications of employees, or a concentration of scientific and technical potential: These are extremely important for the development of depressed regions. A multiplier effect of the development of the tourism industry is based on its influence on such key sectors of the economy as transport, communications, construction, and agriculture, and thus, tourism can be considered a certain trigger of the socio-economic development of the region.

Therefore, the government is taking measures to develop domestic tourism, elaborating road maps for the development of tourism in the regions and such incentive programs as tourist cash back. According to Ostrovok.ru (online Russian hotel-booking service) estimates, every day up to $40 \%$ of bookings in Russian cities had been made within the framework of this cashback program in April 2021 [38]. At the same time, the number of people who want to relax within the country is also related to changes associated with the spread of COVID-19 infection. For example, about 260,000 visitors came to Sochi for the New Year holidays; the city was visited by 30,000 more tourists in December less than a year earlier [39].

However, for more than 20 years, Sharpley has promoted the concept that sustainable development through tourism is unfeasible [40]. The author divorces sustainable tourism per se and tourism-based sustainable development. Meanwhile, an avalanche of papers devoted to sustainable tourism has filled literature resources in the last decade: It might be estimated at significantly more than 5000 [41]. Even though the problem is multifaceted and multi-relational (multiply connected), it mostly has been linked to climate change [42]. To continue further discussion of whether standard economic growth-based policies (and tourism in particular) are in line with the goals of a safer and more sustainable world, researchers should untangle this complex problem with contradictions of numerous stakeholders. In this regard, an essential shift from a concentration on theoretical aspects toward a focus on applied issues was noted [42]. 


\section{General Research Methodology}

Methods of similar works are presented by a wide spectrum of publications, e.g., in $[43,44]$.

In this study we highlight that network science covers both many thorough theoretical domains and rough empirical ones with an enormous number of actors involved in exaggerated relations.

It has been noted that a key principle in network science is that real-world complex system behavior is due to the structure, rather than the properties of the nodes.

Compared with conventional domains, network science pays more attention to links than objects; thus, processes are also analyzed on a network-based platform. Being converted into a network, an entity might be further applied to scrutinize concomitant topological features with the power of math: probability theory, linear algebra, graph theory ...

The problem concerning utilizing network science for the clarification of sustainability in the sphere of tourism is twofold: networks for sustainable development [45] and networks for tourism [46].

Mapping entities with network-like and network-unlike appearances promotes a pervasive analysis of tourism destinations and concomitant systems in one silo-network space.

This space is constructed by advanced models oriented toward the integration of sets of elements of diverse nature to make up a whole. As [47] mentioned, the objective of creating a tourism destination within a smart conception becomes an indispensable condition toward its sustainable development. To follow such an idea as a paramount one, we built our study on a network platform (network forma mentis) and implemented network-based analysis to all the processes and objects within the considered systems.

Considering the terrain system as a whole, through a holism prism, network science provides its instruments to uncover hidden interconnections of numerous actors and groups of actors.

Taking into account these interdependencies within comprehensive network space, it is of value that the environmental component be left as intact and unspoiled as possible while developing the socio-economic and technological sphere of the studied area.

In line with the network paradigm, the work [43] paid attention to modern Internetbased social network instruments in terms of their impact on learning processes and found through questionnaires and corresponding responses a negative effect that impedes education sustainability.

The spatial factor and neighboring were connected with sustainable development and property value in [44].

Network thinking was used in all aspects to clarify the problem toward sustainable development in the study area (Figure 2). Numerous databases and additional field interviews supported the research to achieve the goal.

Thus, each step we went through in the study was in line with the methodology, which connected all the data and processes in diverse domains into a single whole.

Tracing links in the network-based space promotes the elaboration of both a roadmap for further sustainable tourism development and the sustainable development of the territory. 


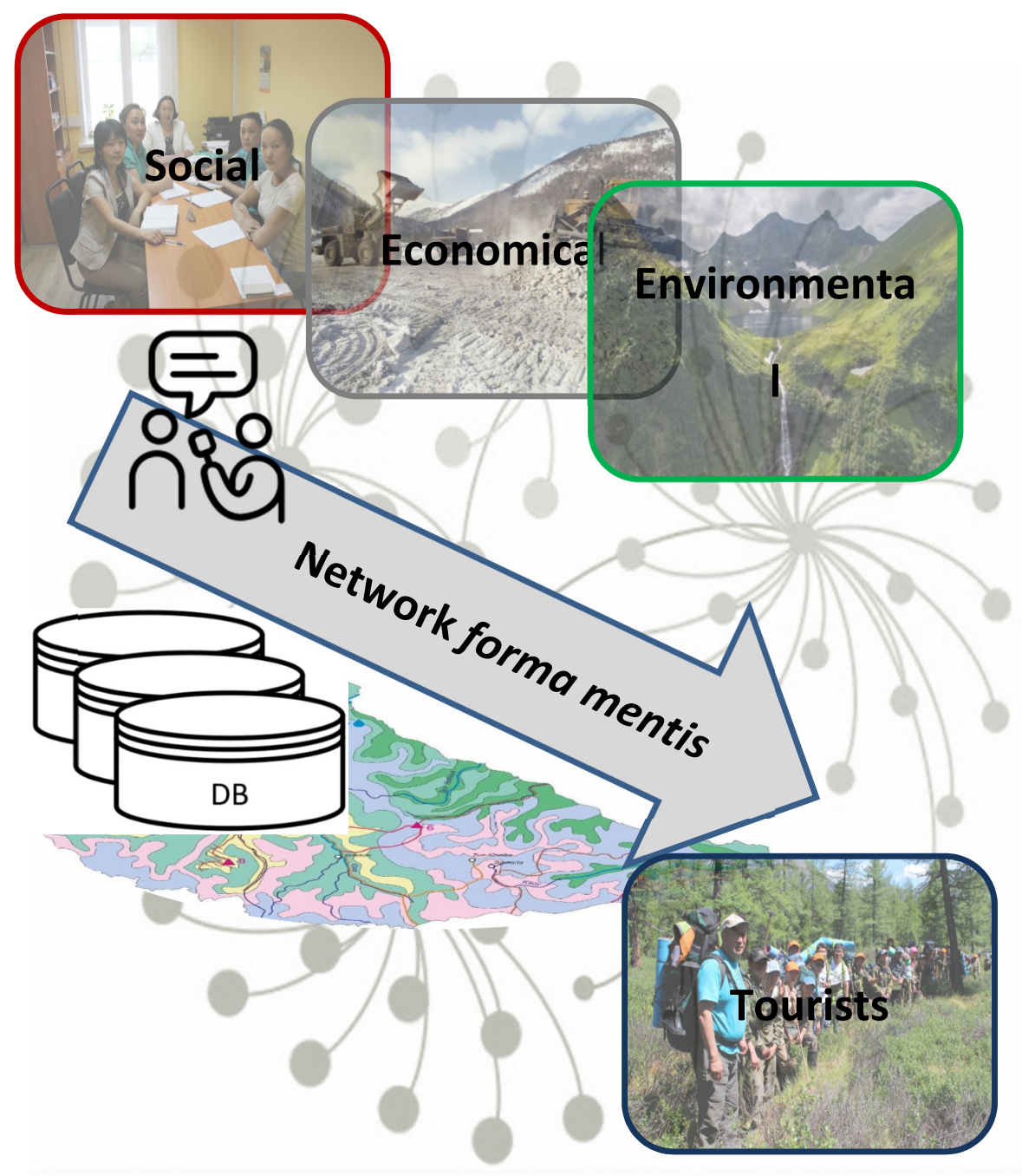

Figure 2. Network-based research methodology.

\section{Study Area}

As one knows, the Republic of Buryatia borders Mongolia, which naturally affected the history. Okinsky District, in comparison with other border Buryat districts, occupies one of the largest territories of the border. The territory of the region is characterized as an area with an extremely harsh climate, inaccessibility, and richness of mineral resources. The area extends to almost $26,600 \mathrm{~km}^{2}$.

After the Republic of Buryatia became part of the Far Eastern Federal District, the financial resources at the disposal of the Okinsky Municipal Formation increased significantly. Despite this, the district administration continues to search for options for the harmonious development of the region's economy. The main payers to the regional budget are mining enterprises, and they also play a significant role in creating jobs in its territory. However, the expansion of existing and the opening of new mining enterprises can significantly worsen the ecosystem of the territory. In this regard, the tourism business can become one of the drivers of economic growth in the region.

Okinsky District is quite interesting from the point of view of health tourism [48]. The most interesting attraction from the point of view of tourist and recreational resources is the mineral waters. The wide variety is determined by the complex geological structure of the region, its high neotectonic activity, and recent volcanic activity. A significant part of the outlets of mineral waters is located at high altitudes, with absolute marks of 1500-1700 m (Zhoigan, Shutkhulai, Shumak), and are confined to river valleys [49]. 
Zhoygan (Choigan) is located on the territory of the traditional settlement of indigenous peoples- the Soyots and Tuvans-Tozhins. There is no tourist infrastructure around the springs, except for log cabins at each bath, a bath, and two toilets. At the same time, it has become generally accepted to distinguish between groups of tourists and vacationers.

Vacationers are residents of neighboring settlements of Okinsky District of the Republic of Buryatia and the Todzha kozhuun of the Republic of Tuva, as well as related relatives, friends, and other ties among residents of other kozhuuns of Tuva and the regions of Buryatia, for whom the springs are the final and sometimes the only destination. Tourists in this context are residents of other territories, for whom the springs are only one of the places on a long route associated with active tourism: rafting, kayaking, horse and hiking tours, mountain biking, and lakes that attract amateur fishers. Topografov Peak is located within five kilometers of the springs, which attracts the attention of snowboarders even in summer. The distance between the village of Orlik and the foot of the pass closest to the Zhoigan mineral springs is between 70 and $100 \mathrm{~km}$ and is overrun by residents of Okinsky District in trucks.

The differences in the distance estimates are related to the peculiarities of the route: About $10 \mathrm{~km}$ pass through the swamp, and the time spent crossing depends on many factors. On average, it takes about $10 \mathrm{~h}$, but it can take several days if the car gets stuck. At the foot of the pass is a winter hut, which has grown into a base where locals rest, offering their horses for transporting tourists and their goods, as well as tourists on their way to the mountains. Such winter huts and the free use of them are not an exception, but rather an example of a widespread practice of staying in hard-to-reach areas.

Nearby, in Okinsky District, are the Khoytogol springs, where in the 1990s a sanatorium was built with five buildings, a dining room, a swimming pool, and a pipe from the hot springs to heat one of the buildings. However, due to the transfer of tax payments to the republican and federal budgets and the lack of competent management, the sanatorium was closed. The remaining infrastructure is used by free arriving tourists and local residents. In addition, schoolchildren from the boarding school of the neighboring village of Sayan use it as a children's sports and health camp [50].

The waters of the Shumak springs belong to a rather rare type in nature, which is called Shumak. Mineral waters are unloaded both along the left and right banks of the Shumak River, concentrating in three groups stretched along the riverbed, traditionally called "lines." The total number of sources is about 200. Back in the 1960s, near the springs one could see tablets with inscriptions in the old Mongolian language indicating a disease or an organ that could be healed there. Now the signatures are made in Russian and regularly updated. The balneological effect of mineral waters is determined by many criteria, primarily mineralization, ionic composition, gas saturation, the content of pharmacologically active microelements, and other characteristics [49].

The need to take into account tourist flows in this territory is primarily due to the prospects for involving local residents in the tourism business-it is necessary to develop a culture of hospitality and create or expand the range of tourist services provided. At the same time, it is necessary to avoid the risks of privatization of recreational resources, which is already taking place at the Shumak mineral springs. As a result of the creation of a tourist base, the houses, which were built before the appearance of the new owner and were used by all those in need, are now offered for rent at a price much higher than the standard prices on the shore of Lake Baikal [51].

In addition, control over the flow of tourists is needed to ensure the work of searchand-rescue teams. In Sayan, the nearest point of the Ministry of Emergency Situations is in the Village of Mondy. When traveling to the territory of the Sayan Mountains, tourists must register by writing down the day of entry and the day of their planned departure. On the way back, tourists must sign to confirm their departure. Otherwise, three days later, the rescue group begins search operations in vehicles, although the bulk of the mountainous territories still remains inaccessible to this type of transport [50]. 
In addition, information on tourist flows is necessary to determine the anthropogenic load, which is especially great when using trucks and off-road vehicles: swamp and tundra ecosystems are easily destroyed and recover slowly. For local residents using horses and deer, the passage of heavy equipment interferes with horse trails. The line between amateur fishermen and poachers is also very shaky: It is obvious during the spawning season, but at other times the restrictions on catching valuable fish species are difficult for representatives of the fishery supervision to control. At the same time, the difference between locals and tourists is not so obvious: Both of them can use trucks or move on horses, and engage in poaching or feeding wild animals.

In terms of maintaining highways and ensuring transport accessibility, when studying the latter, researchers usually rely only on existing paved roads and road and rail transport; as far as winter roads, there are only those of federal significance. In the case of hard-to-reach areas, this approach is limited. In particular, technological and local roads remain unaccounted for. In addition, the types of non-motorized transport (horsedrawn, bicycles), snowmobiles, all-terrain vehicles, and various types of small-sized water transport are also ignored. Despite their scarcity, their very presence changes the idea of transport accessibility.

The network scope puts the data presented above into one network silo and further field practice brings R\&D elements to comprehensive observation.

\section{Results}

The investigated Okinsky region is the westernmost region of the Republic of Buryatia. This feature causes difficulties in the form of remoteness from the capital of the republic, the city of Ulan-Ude. But at the same time, the advantage of the geographical location of the region is that it borders Mongolia, the Republic of Tuva, and the Irkutsk region [52]. This feature gave rise to the formation of a new international tourist destination: BaikalKhövsgöl-Tuva. The development of this area is facilitated by a number of positive conditions, such as:

The presence of a high interest in Lake Baikal from foreign tourists, as well as Russian tourists to Lake Khövsgöl;

The prospect of building a passenger crossing at Mondy-Khanh on the RussianMongolian border;

Positive dynamics in the development of ecological tourism infrastructure on Lake Khövsgöl [53].

The terrain is typically alpine relief, mountainous terrain interspersed with plateaulike elevations, with narrow valleys and many rivers and streams. Alpine meadows on the slopes of the ridges are used as distant pastures in the summer. According to the census, the entire population of the district is 5470 [54]. Thus, we can say that the geographical feature of the area has a special individual characteristic, and this gives certain advantages, such as a varied structure, picturesque landscapes, etc. Of course, nature itself is the most important source and resource of tourism. The area is replete with natural monuments, untouched wildlife, and ethnic and national cultural heritage.

Several areas of development were identified in the area under consideration: mining, traditional farming (cattle breeding, hunting, gathering), and tourism. Currently, the district administration sees the mining industry as the most promising area for the development of the district, which in the future will allow for infrastructural development, improvements in the quality of roads, the development of power lines, the creation of new jobs, and an increase in the economic indicators of the district. Within the research, 18 interviews were conducted with key local persons (those who represent administrations, phratries, and businesses). "The only way for us to extend this line (a reliable power transmission line on concrete cushions) is an economic indicator for consumption. If here are our subsoil users ... now our territory of the Okinsky region is included in the TAD (territory of advanced development) of Buryatia at the expense of 3 enterprises: the Baikal financial and industrial company, which is engaged in the extraction of quartzite at the Urdagagan deposit, Khuzhir-enterprise ... They are not a 
new enterprise, they are in the TAD entered, as it were, to modernize an existing enterprise. And we also have Rihei Limited Liability Company ... They also like modernization. Here are 3 enterprises that gave us at least a little hope to provide an economic component for broaching the line. But everything depends on their results ... There are supposed to be up to 2.5 thousand employees, that is, this is a large enterprise and it is already economically profitable. That is, there are no other reasons for building a power transmission line for us. Not yet. Here this economic underpinning in this part can help" (from an interview with a representative of the administration, woman, 48 years old, 2020, in Sorok).

Local residents are very concerned about the environmental situation associated with the development of existing industrial enterprises and plans to develop new deposits. "From the fact that we are remote nature has been preserved in its original form. But recently, more than 30 licenses for the development of minerals were issued on the territory of the Okinsky District. Only on the territory of our settlement there are about 20. We were always proud that we have the cleanest air, the cleanest water, yet water comes from here. And now all the licenses will work, I don't know what will happen" (from an interview with an administration representative, 2020). "But, unfortunately, we will not make it to the park, we have gold mining work here, nature is spoiled. In Samart there is a gold mining factory, a cyanide cushion that can burst at any moment, and the cyanide will run and everything will go to Oka, throughout the Irkutsk region. It's not only Oka residents who suffer, but in the Tunkinsky district all the effluents from the factory go into the water, so there are a lot of cancer patients ..." (from an interview with a medical worker, woman, 65 years old, 2000, in Orlik).

The cumulative attitude of local residents toward tourists is reflected in Table 1.

Table 1. Attitude of local residents to tourists in Okinsky District.

\section{Respondents}

Female, medical worker, 65 years old, Orlik

Female, cultural worker, 47 years old, Orlik

Male, administrative worker, 49 years old, Orlik

Female, representative of education, 50 years old, Sayan

Female, administrative worker, 49 years old, Sorok

\section{Quotes from Respondents}

"Of course, I understand, on the territory of the Russian Federation, please, but I want the Okinsko-Tunki park to be made and banned from sailing along the rivers with their windmills. So that tourists come just to see. They act in a barbaric way. Sometimes fish are taken out in whole barrels. And we don't know, maybe they hunt, we can't check everyone, it's not allowed by law. There used to be a border zone, until the 1990s, there was a strict regime here and they did not have the right to travel. Tunkinsky, Okinsky, Zakamensky districts-all border areas, if they restored it, I would be very pleased ..."

“... I think it's good that we didn't make the road, anyway there is a deterrent factor. Even now, people are driving in bulk, and even though the road is bad ... they also catch our natural resources, kindle fires. It has become very fashionable to come by motor boats and to ride frightening fish."

"In fact, they tried to encourage people to do this, but we have the specificity of animal husbandry, it is like this, every month there is scheduled in its own way, who, what, when they do ... His main source of income is animal husbandry, which he has known from time immemorial. He knows, I'll raise this calf and in a year and a half, he will give me 150 $\mathrm{kg}$ of meat, so, here, too, you have to step over this one. There is no time to provide services there or has never provided, and now provide? To clean up, wash someone else's bed, wash the baths are the same, well, this one, purely such a mental ..."

"They (tourists) do not go to villages, they leave for wild springs (Zhoigan, Khoytogol). We have parking there, and they offer milk and sour cream there ... We have no guest houses here yet. So far none of ours has woken up or something."

"We usually have a lot of people traveling in the summer. Alloy. Solitary tourists walk. Foreigners come to us whoever is not there in general." 
The analysis of the interviews showed that the local population understands that tourism should be responsible, not damaging the environment. It was noted that the local population is not yet paying attention to this perspective, and is working on developing a traditional economy. The peculiarities of cattle breeding can be seen from this interview: "We have specificity in the hauls. Moving cattle from pasture to pasture is about 4 times a year. These are distances, these are additional migrations, well, and the conditions ... not everywhere there is such, say, a warm, solid house. Well, even if you have overtaken and do not live there, it is periodically necessary to go there, long distances, through the passes, there is snow, rain. That is, the severity of the climate, it also leaves an imprint on the component of the product. And nobody takes this into account in theory ... it is much more difficult here to raise livestock, well, marketable livestock for sale. Well, the specifics are. But, nevertheless, local people live by this natural economy ... here it has its own specifics in this regard, well, it is clear that not all animals can survive here, yes. Initially, this is from time immemorial-yak breeding, horse breeding, reindeer breeding. Those. we also have reindeer here. We now have a municipal herd of about 60-odd heads" (husband, representative of the administration, 49 years old, Orlik).

One of the respondents emphasized that tourism still generates income for people who provide services to tourists. "We are very developed: they take tourists from Orlik to the pass, they also earn money, that is, they provide a lorry. horse 2.5 thousand there back, there you need to go through the pass on horseback. This was the hostess of the hotel, her son built there in a cafe, or whatever base, they also meet at home. There is a dining room, and there are men who deliver freight transport, and there on the way halfway they stop to dine there at the base and continue on, they already provide a horse under the pass" (from an interview with a woman, representative of culture, Orlik, 47 years old).

Despite the numerous attractions and natural prerequisites of the Okinsky region (the presence of natural monuments, mineral and medicinal springs, etc.), tourist activity in the region is not sufficiently developed. According to the official data of the administration, four collective accommodation facilities with a total of 99 beds are registered in Okinsky District. One of them is the well-known and popular Shumak tourist center, with 48 places. According to these placements, the total number of visitors to the area in 2020 was 1700, due to restrictions on entering the area during the peak seasons of the spread of COVID-19, whereas in previous years the number of tourists had increased every year (see Figure 3). The count of the number of tourists in the area is taken according to the data of the collective accommodation facilities. Individual tourists are not counted.

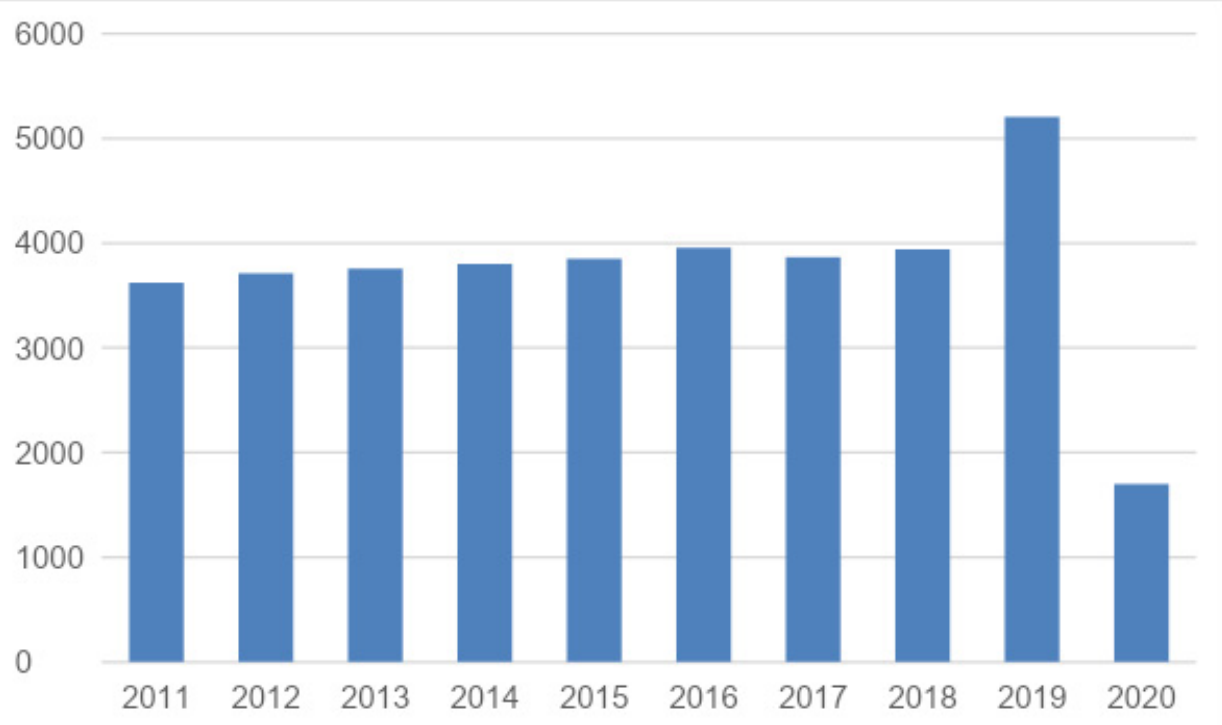

Figure 3. The number of tourists in Okinsky District by year. 
From Table 2, we see that support for tourism development in the area is not stable. Basically, these expenses are aimed at participating in various exhibitions and fairs.

Table 2. Municipal budget expenditures to support the tourism industry by year.

\begin{tabular}{cccccccccc}
\hline Year & $\mathbf{2 0 1 2}$ & $\mathbf{2 0 1 3}$ & $\mathbf{2 0 1 4}$ & $\mathbf{2 0 1 5}$ & $\mathbf{2 0 1 6}$ & $\mathbf{2 0 1 7}$ & $\mathbf{2 0 1 8}$ & $\mathbf{2 0 1 9}$ & $\mathbf{2 0 2 0}$ \\
\hline Thousand RUB & 50 & 990 & 365 & 49.93 & 0 & 0 & 12 & 24 & 0 \\
\hline
\end{tabular}

Information about available tourist centers is most often learned through word of mouth. "We don't have a website, they find it through acquaintances, some call in, ask the locals, they send them to us" (Forty, 52 years old, woman, hostess). That is, we saw that informal networks are developed in remote and hard-to-reach areas. For example, in order to leave for Irkutsk, a group gathers in Viber and the minibus driver carries out transportation as the minibus gets full. Even many residents are interested in frequent visits to Irkutsk city; however, there is no official route to Irkutsk.

\section{Discussion}

The network approach concerns numerous actors throughout all the components of the territory system: social, economic, and environmental subsystems.

Thus, local residents understand the uniqueness of their territory, as well as its advantages, attractiveness for tourists, and the environmental risks associated with the extractive industry. Sustainable tourism could become a strategic direction for the development of this area.

Contrary to the exploration of the impact of rural migrants on city slums [44], this study promotes questions on the effects of numerous tourists in territories with intact nature and sparse populations.

The study territory is characterized by a local native population who are indigenous to Okinskiy District: the soyot people. Diverse harmful factors concomitant to sustainable tourism development might jeopardize their cultural distinction, thereby evoking a defensive, closure-oriented reaction among native people [55].

Another paper [56] pointed out that the effect of tourism activity on cultural heritage is twofold. On the one hand, such a practice promotes the conservation of cultural traditions, whereas on the other hand, tourism development provokes changes within a local society that make the destination lose its cultural authenticity.

Moreover, there might be some conflicts among residents and visitors that are provoked by the imbalanced number of local people and tourists and indecent behavior by the latter [57].

It is of value to combine qualitative data with digital representation to more deeply understand how the prospective of sustainable tourism impacts locals and vice versa. Thus, the structures of formal and informal social ties found in the field examination somewhat clarify the information interconnections between tourists and residents.

These ties control professional and social activities through the respective information channels. Formal information sharing is supported by professional and administrative contacts with hierarchical topology (Figure 4a). Naturally, kinship and friendship interconnections provide informal information spreading. The informal communication is represented by dense ties inside pertinent components connected by sparse outer links (Figure 4b).

Nowadays, the tourism industry, burdened with environmental and social responsibility, feels demand from governments and societies to follow the culture of sustainability in all pertinent operations. Thus, a question arises that needs to be clarified: How can the low-damage development of a remote tourism destination be achieved simultaneously with its sustainability? Naturally remote and sparsely populated territories with poor transportation availability might propose a tourism product that is focused mainly on health and recreation. 

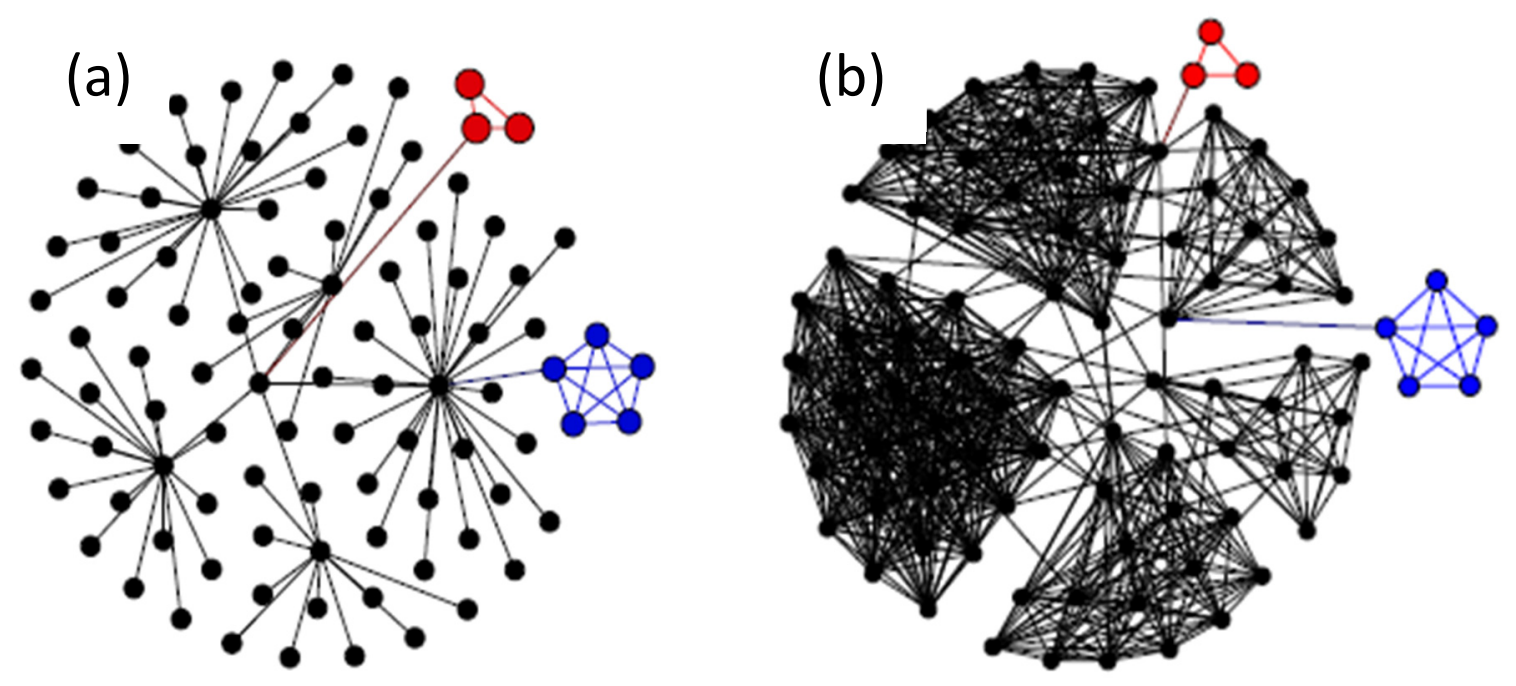

Figure 4. Toy pictures of formal administrative links (a) and those for informal relations (kinship and friendship (b) within a local community, including touristic groups (represented by red and blue nodes).

If following the methodology of the authors of [34], first, for further development of the current study, it makes sense to seek out evaluation metrics that reflect low-damage development.

Some researchers have suggested how crisis might clarify meaning and provoke discussion of a given system state [58].

Crisis can prescind from the structural weakness of the system and focus on the outer sides of the event. Thus, crisis hides its roots in social, economic, and environmental topological vulnerabilities and even threats that are stimulated by vulnerabilities [59].

At the same time, crisis might be treated as a means to uncover structural contradictions and errors in a system. Network science scrutinized many disaster and emergency cases just to serve as a powerful instrument to assess the topological robustness of tourism constructions.

It is of value that such investigations might be useful to support decision-making by government officials.

\section{Conclusions}

The prospects for the development of tourism in the Okinsky region are very high because the territory has numerous unique tourist destinations. Despite the presence of various attractions in the Okinsky region (natural monuments, mineral and medicinal springs, etc.), tourist activity in the region is still underdeveloped.

The key factors hindering the development of tourism in the district include:

- The inaccessibility and remoteness of the territory in general, and most of the tourist attractions; - Harsh climatic conditions determining the pronounced seasonality of modern tourist flows to the region;

- Poorly developed infrastructure, including transport, communication, hotels, etc.;

- Lack of branding of the territory and available information about tourist places;

- Lack of readiness of the local population for employment in the field of tourism services, and only a few examples of the provision of transport services and housing.

The development of cooperation between Russia and Mongolia in the field of tourism in 2014 was marked by a bilateral agreement on visa-free tourist exchange [60]. Such an agreement provides tremendous opportunities for the development of tourism not only in the Okinsky region, but also in Russia as a whole. However, for the successful operation of the structure, a full-scale development of the entire infrastructure of the district is necessary. The borders are currently closed due to restrictions associated with the pandemic. However, once the restrictions are removed and taking into account the roadmap 
for tourism development in Buryatia, one will see good prospects for the development of cross-border tourism with Mongolia.

The study area is rich in balneological and recreational resources. The possibilities of using mineral springs for the treatment of a wide range of diseases, combined with an attractive natural landscape, make it possible to consider this tourist destination as one of the most promising. To provide tourists with quality services, a serious contribution is needed from all the main components of the infrastructure of the subject industry, taking into account the territorial specifics, with the subsequent formulation of practical proposals for the development of tourism in this territory. It is important to note that with a balanced and comprehensive development of the tourism sector and its infrastructure, an increase in the standard of living of the local population can be predicted.

Thus, for further studies it is of value to advance with a thorough quantitative network model of the tourism sector of the destination comprising socio-economic and environmental components. It is of value to fill the model with additional data from interviews with a statistically significant number of residents, tourists, tourism industry representatives, and local and regional officials. A key step implies the comparison of network-based markers and indicators of balanced and sustainable tourism development just to connect them.

Author Contributions: All authors substantially contributed to this paper. They participated in conceptualization (M.K, A.T.), data analysis (M.K., N.K., D.K.), and writing the outcomes (A.T., N.U., M.B.). M.K. participated in field expeditions by conducting interviews and collecting data through the process of participant observation. All authors have read and agreed to the published version of the manuscript.

Funding: The study was funded by RFBR and MECSS, project number 20-57-44002, "Interdisciplinary network platform for modeling socio-economic and environmental processes in the cross-border territories of the Russian Federation and Mongolia with limited transport accessibility."

Institutional Review Board Statement: The study was conducted according to the guidelines of the Declaration of Helsinki, and approved by the Ethics Committee of the Irkutsk National Research Technical University (Code U-175).

Informed Consent Statement: Informed consent was obtained from all subjects involved in the study.

Data Availability Statement: The dataset used during the current study is available from the corresponding author on reasonable request.

Conflicts of Interest: The authors declare no conflict of interest. The funders had no role in the design of the study; in the collection, analyses, or interpretation of data; in the writing of the manuscript, or in the decision to publish the results.

\section{References}

1. Latour, B. Reassembling the Social: An Introduction to Actor-Network Theory; Oxford University Press: Oxford, UK, $2005 ; \mathrm{p} .301$.

2. Gungaadash, B. Economic Geography of Mongolia; Authorized translation from Mongolian; Progress: Moscow, Russia, 1984; p. 248.

3. Vetrova, E. Trends in the Development of Services in the World Economy. TSU Herald. Issue 2018, 10, 367-370. Available online: https:/ / cyberleninka.ru/article/n/tendentsii-razvitiya-sfery-uslug-v-mirovom-hozyaystve (accessed on 1 May 2021).

4. World Bank Official Website. Available online: www.worldbank.org (accessed on 10 May 2021).

5. Barbier, E.B. The Concept of Sustainable Economic Development. Environ. Conserv. 1987, 14, 101-110. Available online: http:/ / www.jstor.org/stable/44519759 (accessed on 11 May 2021). [CrossRef]

6. Elliott, J.A. Sustainable development. Int. Encycl. Hum. Geogr. 2009, 117-131. [CrossRef]

7. Dernbach, J.C. Achieving sustainable development: The Centrality and multiple facets of integrated decisionmaking. Indiana J. Glob. Leg. Stud. 2003, 10, 247-285. [CrossRef]

8. Hák, T.; Janoušková, S.; Moldan, B. Sustainable development goals: A need for relevant indicators. Ecol. Indic. 2016, 60, 565-573. [CrossRef]

9. Mensah, J. Sustainable development: Meaning, history, principles, pillars, and implications for human action: Literature review. Cogent Soc. Sci. 2019, 5, 1653531. [CrossRef]

10. Shimova, O. Sustainable Tourism; RIPO: Minsk, Belarus, 2014; p. 158. Available online: http://tempus.bseu.by/files_new1/09_21 11_ustoich_turism.pdf (accessed on 17 May 2021).

11. State Standard RF ISO 14050-2009. Available online: https:/ / docs.cntd.ru/document/1200081854 (accessed on 15 May 2021).

12. Tulokhonov, A.K. Baikal: Nature and People. Encyclopedic Reference Book; EKMOS: Ulan-Ude, Russia, 2009 ; p. 608. 
13. Evstropyeva, O.V. Ethnorecreational potential of the Baikal region. Geogr. Nat. Resour. 2013, 1, 127-135. Available online: http:/ / www.izdatgeo.ru/pdf/gipr/2013-1/127.pdf (accessed on 21 May 2021).

14. Abalakov, A.D.; Pankeeva, N.S. Features of tourism development during the global economic crisis. Geogr. Nat. Resour. 2011, 3, 111-117. Available online: http:/ / www.izdatgeo.ru/pdf/gipr/2011-3/111.pdf (accessed on 18 May 2021).

15. Lorentzen, A. The development of the periphery in the experience economy. In Development in Northern Europe; Routledge: London, UK, 2012; pp. 16-29.

16. Melnik, L. Development Economy: Monograph; University Book: Sumy, Ukraine, 2006; p. 289.

17. Bobylev, S.; Subarevich, N.; Vlasov, Y.; Solovyova, S. Sustainability: Methodology and Measurement Techniques; Economics: Moscow, Russia, 2011; p. 358.

18. Mamirkulova, G.; Mi Mahmood, S.; Mubeen, R.; Ziapour, A. New Silk Road infrastructure opportunities in developing tourism environment for residents better quality of life. Glob. Ecol. Conserv. 2020, 24, e01194. [CrossRef]

19. Abbas, J.; Mubeen, R.; Iorember, P.T.; Raza, S.; Mamirkulova, G. Exploring the impact of COVID-19 on tourism: Transformational potential and implications for a sustainable recovery of the travel and leisure industry. Curr. Res. Behav. Sci. 2021, $2,100033$. [CrossRef]

20. Girenok, F. Ecology. Civilization. Noosphere; Nauka: Moscow, Russia, 1987; p. 180.

21. Treshnikov, A. Geographic Dictionary; Soviet Encyclopedia: Moscow, Russia, 1986; p. 28.

22. Kuznetsov, E. The Formation of Anti-Globalization Ideology in Western Countries: The 1970s and 1990s; ISU: Irkutsk, Russia, $2004 ;$ p. 193.

23. Maksarova, E. The main areas of implementation of the principles of sustainable development in tourism. Izv. Herzen Univ. J. Humanit. Sci. 2008, 85, 345-350.

24. The Dynamics of Demand for Tourist Services in Russia against the Background of the COVID Pandemic-19 Scientific Reports Bulletin on Current Trends in the Russian Economy. Available online: https://ac.gov.ru/uploads/2-Publications/BRE/BRE_68 .pdf (accessed on 17 May 2021).

25. Defining Sustainable Tourism. Available online: https://www.gdrc.org/uem/eco-tour/sustour-define.html (accessed on 31 May 2021).

26. Pirogova, O.; Pirogova, A.; The role of sustainable tourism in the world. Int. J. Appl. Fundam. Res. 2017, 7, 305-309. Available online: https: / / applied-research.ru/ru/article/view?id=11743 (accessed on 26 May 2021).

27. International Council of Local Environmental Initiatives, International Development Research Centre and UN Environmental Programme. Local Agenda: Planning Guide, XXI; IDRC: Toronto, ON, Canada, 1996; p. 178.

28. Aman, J.; Abbas, J.; Mahmood, S.; Nurunnabi, M.; Bano, S. The influence of Islamic religiosity on the perceived socio-cultural impact of sustainable tourism development in Pakistan: A Structural Equation Modeling Approach. Sustainability 2019, 11, 3039. [CrossRef]

29. Hospitality Industry: All Your Questions Answered. Available online: https://hospitalityinsights.ehl.edu/hospitality-industry (accessed on 19 May 2021).

30. Secretary-General's Policy Brief on Tourism and COVID-19. Available online: https://www.unwto.org/tourism-and-covid-19 -unprecedented-economic-impacts (accessed on 17 May 2021).

31. Bramwell, B.; Lane, B. Sustainable tourism: A developing global approach. J. Sustain. Tour. 1993, 1, 1-5. [CrossRef]

32. Rasoolimanesh, S.M.; Sundari, R.; Michael Hall, K.; Esfandiar, K.; Seyfi, S. Systematic review of indicators of sustainable tourism in relation to the goals of sustainable development. J. Sustain. Tour. 2020, 1-21. [CrossRef]

33. Hunter, K.J. On the need to rethink sustainable tourism development. J. Sustain. Tour. 1995, 3, 155-165. [CrossRef]

34. Zhang, J.; Zhang, Y. Assessing the low-carbon tourism in the tourism-based urban destinations. J. Clean. Prod. 2020, $276,124303$. [CrossRef]

35. Budeanu, A. Impacts and responsibilities for sustainable tourism: A tour operator's perspective. J. Clean. Prod. 2005, 13, 89-97. [CrossRef] [PubMed]

36. Introduction Biodiversity and Tourism Convention on Biological Diversity. Available online: https://www.cbd.int/tourism/ intro.shtml (accessed on 24 May 2021).

37. Sustainable Development. Available online: https://www.unwto.org/sustainable-development (accessed on 17 May 2021).

38. High Demand: Turkey's Closure Has Affected Rental Housing on the Black Sea. Available online: https:/ / realty.rbc.ru/news/60 79426c9a794730d2b21a41 (accessed on 25 May 2021).

39. The Flow of Tourists to Sochi Exceeded the Pre-Pandemic Indicators. Available online: https://www.kavkaz-uzel.eu/articles/35 8251/ (accessed on 10 May 2021).

40. Sharpley, R. Tourism, sustainable development and the theoretical divide: 20 years on. J. Sustain. Tour. 2020, 28, 1-15. [CrossRef]

41. Ninerola, A.; Sanchez-Rebull, M.-V.; Hernandez-Lara, A.-B. Tourism research on sustainability: A bibliometric analysis. Sustainability 2019, 11, 1377. [CrossRef]

42. Moyle, B.; Moyle, C.; Ruhanen, L.; Weaver, D.; Hadinejad, A. Are we really progressing sustainable tourism research? A bibliometric analysis. J. Sustain. Tour. 2020, 29, 1-17. [CrossRef]

43. Abbas, J.; Aman, J.; Nurunnabi, M.; Bano, S. The impact of social media on learning behavior for sustainable education: Evidence of students from selected universities in Pakistan. Sustainability 2019, 11, 1683. [CrossRef]

44. Hussain, T.; Wei, Z.; Ahmad, S.; Xuehao, B.; Gaoli, Z. Impact of urban village disamenity on neighboring residential properties: Empirical evidence from Nanjing through hedonic pricing model appraisal. J. Urban Plan. Dev. 2021, 147, 04020055. [CrossRef] 
45. Weber, J.M.; Lindenmeyer, C.P.; Lio, P.; Lapkin, A.A. Teaching sustainability as complex systems approach: A sustainable development goals workshop. Int. J. Sustain. High. Educ. 2021, 22, 25-41. [CrossRef]

46. Baggio, R. Network Analysis Methods Encyclopedia of tourism management and marketing; Buhalis, D., Ed.; Edward Elgar Publishing: Cheltenham, UK, 2021; Available online: https:/ / www.iby.it/turismo/papers/rb_net_encycl.pdf (accessed on 12 May 2021).

47. Baggio, R. Digital Ecosystems, Complexity and Tourism Networks. In Handbook of E-Tourism; Springer: Berlin/Heidelberg, Germany, 2020. [CrossRef]

48. Rossikhin, A.I. The Current State and Prospects of Tourism Development in the East Sayan Tourist and Recreational Mountain Territory. In Proceedings of the I International Scientific and Practical Conference, Gorno-Altaisk, Russia, 26-27 April 2018; Available online: http:/ / case.asu.ru/files/form_312-32208.pdf (accessed on 21 May 2021).

49. Shpeizer, G.M.; Makarov, A.A.; Rodionova, V.A.; Mineeva, L.A. Shumak's mineral waters. Izv. Irkutsk. Gos. Univ. 2012, 5, 293-309. Available online: https:/ / cyberleninka.ru/article/n/shumakskie-mineralnye-vody/viewer (accessed on 25 May 2021).

50. Kuklina, V.V. Tourists and vacationers on the mineral springs of Joigan/Choigan: Social connections, nodes, networks and borders. Cult. Humanit. Geogr. 2012, 2, 180-190. Available online: https://gumgeo.ru/index.php/gumgeo/article/view/55 (accessed on 24 May 2021).

51. The Cost of Vouchers to the Shumak Campsite in 2021 Shumak Tourist Base. Available online: http:/ / shumak.ru/stoimostputevok (accessed on 19 May 2021).

52. Bochkareva, E.N. Mountain ecosystems of Southern Siberia: Study, protection and rational use of natural resources. Sec. Interreg. Scient. Pract. Conf. 2010. Available online: http:/ / www.csbg.nsc.ru/uploads/redkie/Elisafenko/2001-2010\%207.pdf (accessed on 10 May 2021).

53. Amarjargal, P. The Baikal-Khubsugul project. Young Sci. 2016, 29, 623-625. Available online: https://moluch.ru/archive/133/37 247 / (accessed on 15 May 2021).

54. Angapova, O.B. Classification of the border regions of the Russian Federation. Bull. BSU 2014, 2, 76-79. Available online: https: / / cyberleninka.ru/article/n/klassifikatsiya-prigranichnyh-regionov-rossiyskoy-federatsii/viewer (accessed on 18 May 2021).

55. Morris, M.W.; Mok, A.; Mor, S. Cultural identity threat: The role of cultural identifications in moderating closure responses to foreign cultural inflow. J. Soc. Issues 2011, 67, 760-773. [CrossRef]

56. Li, Y. Heritage tourism: The contradictions between conservation and change. Tour. Hosp. Res. 2003, 4, 247-261. Available online: http:/ / www.jstor.org/stable/23743841 (accessed on 27 May 2021). [CrossRef]

57. Postma, A.; Schmuecker, D. Understanding and overcoming negative impacts of tourism in city destinations: Conceptual model and strategic framework. J. Tour. Futures 2017, 3, 144-156. [CrossRef]

58. Masco, J. The Crisis in risis. Curr. Anthropol. 2017, 58, S65-S76. [CrossRef]

59. Barrios, R.E. What does catastrophe reveal for whom? The anthropology of crises and disasters at the onset of the anthropocene. Annu. Rev. Anthropol. 2017, 46, 151-166. [CrossRef]

60. Potaev, V.S.; Atanov, N.I.; Subanakov, G.Y.; Tsyrenov, D.D. Prospects for the development of Russian-Mongolian cross-border cooperation. Bull. BSU 2020, 1, 29-39. 